The University of South Carolina has received a \$350,000 two-year grant from the National Endowment for the Humanities (NEH). Librarians Kate Boyd and Craig Keeney will lead efforts to digitize select South Carolina newspapers published between 1860 and 1922. The newspapers, now available only on microfilm, will be made accessible on the Internet through the University Libraries' S.C. Digital Newspapers Project, a joint project of the University Libraries' Digital Activities Center and the South Caroliniana Library. The project will involve scanning about 100,000 pages of newspaper text and providing cataloging information to enhance access to information about the artistic, literary, religious, ethnic, cultural, economic, and political events in South Carolina during one of the most eventful periods of its history. The newspapers will be mounted on the Web site "Chronicling America: Historic American Newspapers" (chroniclingamerica.loc.gov), which presently holds more than 1 million pages of

Ed. note: Send your news to: Grants \& Acquisitions, C\&RL News, 50 E. Huron St., Chicago, IL 60611-2795; e-mail:agalloway@ala.org.

\section{Statement of ownership and management}

College E Research Libraries News is published 11 times a year (monthly, combining July/August) by the American Library Association, 50 E. Huron St., Chicago, IL 60611. American Library Association, owner; David Free, editor. Second-class postage paid at Chicago, Illinois. Printed in the U.S.A. As a nonprofit organization authorized to mail at special rates (DMM Section 423.12), the purposes, function, and nonprofit status of this organization and the exempt status for federal income tax purposes, have not changed during the preceding 12 months.

Extent and nature of circulation. ("Average" figures denote the number of copies printed each issue during the preceding twelve months; "Actual" figures denote the number of copies of single issues published nearest to filing date.) Total number of copies (net press run): Average, 13,862; Actual, 13,508. Total paid/requested historic American newspapers. The site is produced by the National Digital Newspaper Program, a program jointly sponsored by $\mathrm{NEH}$ and the Library of Congress.

\section{Acquisitions}

\section{The Chrystelle Trump Bond Dance and Sheet} Music Collection (1820-1960) has been acquired by Special Collections and Archives at Goucher College in Baltimore. The collection includes more than 1,000 pieces of American and European dance sheet music, and hundreds of dance programs, dance instruction manuals, rare books, and various portfolios of prints and periodical literature documenting social and theatrical dance in America since the early 19th century. Bond, professor of dance at Goucher since 1963, developed the collection to be used as teaching tool documenting the reconstruction of historical dances. The processing of the collection is supported by the Council on Library and Information Resources, which awarded the library a $\$ 200,000$ grant under a national subscriptions: Average, 13,025; Actual, 12,895. Sales through dealers and carriers, street vendors, counter sales, and other non-USPS paid distribution: not applicable. Other classes mailed through the USPS: not applicable. Total paid and/or requested circulation: Average, 13,025 Actual, 12,895. Free distribution by mail: Average, 94; Actual, 89. Free distribution outside the mail: Average, 0; Actual, 0. Total free distribution: Average, 94; Actual, 89. Total distribution: Average, 13,119; Actual, 12,984. Copies not distributed: Office use, leftover, spoiled: Average, 744; Actual, 524. Total (sum of previous entries): Average, 13,863; Actual, 13,509. Percent paid and/or requested circulation: Average, 99.28\%; Actual, 99.31\%.

Statement of ownership, management, and circulation (PS Form 3526, September 2007) for 2009 filed with the United States Postal Service, Postmaster in Chicago, Illinois, September 25, 2009. 
program funded by the Andrew W. Mellon Foundation.

\section{The John Updike Archive, a collection of} manuscripts, correspondence, books, photographs, artwork and other papers, has been acquired by Houghton Library, Harvard University's primary repository for rare books and manuscripts. The archive forms the definitive collection of Updike material, and will make the library the center for studies on the author's life and work. Although portions of the archive were given to the library during Updike's lifetime, they represented only a small fraction of the full collection. For decades, Updike had deposited his papers in the library, but the material was available only with the author's permission, and was not integrated with the material the library owned. Cataloging the newly acquired material so it can be used by scholars is now one of the library's "highest priorities," said Leslie Morris, curator of modern books and manuscripts at Houghton, since the archive will not be available until that process is completed. However, scholars will still be able to access materials given to the library by Updike before 1970, including early short story manuscripts written for the New Yorker; Telephone Poles, Updike's early poetry collection; and nearly complete documentation on the creation of the novel that brought him his first taste of fame, Rabbit, Run (1960).

\section{Papers of composer Ulysses S. Kay (1917-}

95) have been acquired by Columbia University's Rare Book and Manuscript Library. A composer of contemporary symphonic, chamber, and choral music, Kay also wrote five operas, the most substantial and last of which, Jubilee (1976) and Frederick Douglass (1991), were based on themes from African American history. Kay was encouraged by William Grant Still to study music and attended the University of Arizona as an undergraduate. He received a master's in composition from the Eastman School, where he worked with Howard Hanson and Bernard Rogers, and then studied under Paul Hindemith at Yale. After serving in the Navy during World War II, Kay returned to New York to work with Otto Luening at Columbia. Between 1952 and 1968 he worked as an editorial advisor and later as a music consultant with Broadcast Music Inc., building a name for himself as a composer by writing music in the evenings and on weekends. Kay finished his career with two decades as a professor at Herbert Lehman College-CUNY, retiring in 1988. Highlights of the collection include a large number of Kay's scores in manuscript, a substantial collection of press cuttings relating to performances of Kay's works and those of his colleagues, diaries from his student years, and notes for speeches on numerous topics. His correspondence includes letters from William Grant Still and from his wife Barbara Kay during her periods of imprisonment as a Civil Rights activist, and detailed correspondence with librettist Donald Dorr about the construction of his last two operas.

\section{The Paul Chrzanowski Collection has} been received by the William Andrews Clark Memorial Library at UCLA. The collection, consisting of some 72 rare books, has been appraised at just under $\$ 2$ million. Chrzanowski, a physicist at the Lawrence Livermore National Laboratory in Livermore, California, spent 20 years collecting books that were read or might have been read by Shakespeare. The earliest book in the collection, the Cordiale quattuor novissimorum, printed in 1479 by William Caxton, is one of only 11 known copies. The collection also includes five books printed by Wynkyn de Worde, Caxton's successor, and Richard Pynson's edition of Boccaccio's Fall of Princes (1494) among the incunables. Other highlights include a second and a fourth folio of Shakespeare's works (1632 and 1685), a quarto Henry the Sixth (1619), a second edition of the King James Bible (1613), a first edition of Montaigne in English (1603), and the 1550 Piers Plowman. More information about the Clark Library can be found at www.humnet.ucla.edu/humnet /clarklib/. n 